\title{
Penerapan Strategi Pembelajaran Berbasis Masalah dalam Upaya Meningkatan Keterampilan Menulis Teks Negosiasi bagi Siswa SMA Negeri 2 Labuapi
}

\author{
Rojiati \\ SMA Negeri 2 Labuapi, Kabupaten Lombok Barat \\ Corresponding Author. Email: rojiati@gmail.com
}

\begin{abstract}
This study aims to improve the writing skills of negotiation texts through the application of problem-based learning strategies. This research is a classroom action research with the research subjects of class X MIPA 2 SMA Negeri 2 Labuapi consisting of 25 students. The research instrument used tests, observations, document analysis, interviews, and questionnaires. The data analysis technique used in this research was qualitative and quantitative descriptive analysis. The results of this study indicate that in the process there is an increase in student enthusiasm in participating in learning, student interaction in groups, and student attention. This can be shown from the results of observations during the learning process. The product improvement can be seen with the increase in the students' writing value of negotiating text. In the precycle there were 16 students who had not yet completed it and in the first cycle there were still 6 students who had not finished, and in the second cycle it increased again, that all 25 students had all completed. These results indicate that the application of problem-based learning strategies can increase student activeness in teaching and learning activities and can improve writing negotiation text skills for class X MIPA 2 SMA Negeri 2 Labuapi.
\end{abstract}

\begin{abstract}
Abstrak: Penelitian ini bertujuan untuk meningkatkan keterampilan menulis teks negosiasi melalui penerapan strategi pembelajaran berbasis masalah. Penelitian ini merupakan penelitian tindakan kelas dengan subjek penelitian siswa kelas X MIPA 2 SMA Negeri 2 Labuapi yang terdiri atas 25 siswa. Instrumen penelitian ini menggunakan tes, observasi, analisis dokumen, wawancara, dan angket. Teknik analisis data penelitian ini menggunakan analisis deskriptif kualitatif dan kuantitatif. Hasil penelitian ini menunjukkan bahwa secara proses terdapat peningkatan antusiasme siswa dalam mengikuti pembelajaran, interaksi siswa dalam berkelompok, dan perhatian siswa. Hal ini dapat ditunjukkan dari hasil observasi selama proses pembelajaran berlangsung. Peningkatan secara produk dapat dilihat dengan adanya peningkatan nilai menulis teks negosiasi siswa. Pada pra siklus terdapat 16 orang siswa belum tuntas dan pada siklus I masih 6 orang siswa yang belum tuntas, dan pada siklus II meningkat lagi yaitu seluruh siswa yang berjumlah 25 orang semuanya tuntas. Hasil tersebut menunjukkan bahwa penerapan strategi pembelajaran berbasis masalah dapat meningkatkan keaktifan siswa dalam kegiatan belajar mengajar dan dapat meningkatkan keterampilan menulis teks negosiasi bagi siswa kelas $\mathrm{X}$ MIPA 2 SMA Negeri 2 Labuapi.
\end{abstract}

How to Cite: Rojiati, R. (2020). Penerapan Strategi Pembelajaran Berbasis Masalah dalam Upaya Meningkatan Keterampilan Menulis Teks Negosiasi bagi Siswa SMA Negeri 2 Labuapi. Jurnal Teknologi Pendidikan, 5(2), 150-158. Retrieved from http://ojs.ikipmataram.ac.id/index.php/itp/article/view/3063

\section{Pendahuluan}

Mata pelajaran bahasa Indonesia merupakan salah satu mata pelajaran yang ada di dalam kurikulum 2013. Pada mata pelajaran bahasa Indonesia kurikulum 2013, siswa diharapkan aktif dalam kegiatan belajar mengajar, mampu mengembangkan pengetahuan mereka sendiri dengan bantuan buku paket, modul, majalah, koran, internet, atau yang 
lainnya. Dengan demikian di akhir pembelajaran siswa diharapkan dapat mencapai tujuan pembelajaran yang sudah direncanakan oleh guru.

Pada mata pelajaran bahasa Indonesia terdapat empat komponen keterampilan berbahasa yaitu : keterampilan menyimak (listening skills), keterampilan berbicara (speaking skills), keterampilan membaca (reading skills), dan keterampilan menulis (writing skills) (Tarigan, 2008: 1). Empat keterampilan berbahasa tersebut saling berhubungan satu sama lain. Selama ini masih banyak siswa menganggap pembelajaran menulis merupakan suatu pembelajaran yang membosankan dan sulit dilakukan. Rasa membosankan dan kesulitan yang muncul dari diri siswa tidak hanya disebabkan oleh siswa itu sendiri tetapi juga disebabkan oleh guru yang belum berhasil membuat siswa tertarik terhadap pembelajaran bahasa Indonesia terutama pembelajaran menulis.

Pada hakikatnya menulis merupakan suatu kegiatan yang produktif dan ekspresif. Keterampilan menulis tidak akan datang secara otomatis, tetapi harus melalui latihan dan praktik yang teratur (Tarigan, 2008). Keterampilan menulis tidak serta merta bisa kita lakukan, namun harus dengan latihan yang rutin dan teratur. Latihan yang teratur dapat membuat kita semakin mahir dalam merangkai kata dan kalimat menjadi satu paragraf utuh dan sempurna.

Berdasarkan hasil observasi, ada beberapa permasalahan yang ditemui oleh guru dalam pembelajaran menulis. Masalah yang dihadapi oleh guru yaitu, siswa menganggap kegiatan menulis susah dilakukan, strategi pembelajaran yang digunakan oleh guru dalam mengajar menulis masih menggunakan strategi pembelajaran yang konvensional sehingga keaktifan siswa dalam proses pembelajaran masih kurang.

Menyikapi permasalahan tersebut, dibutuhkan suatu strategi pembelajaran yang tepat dalam menulis teks negosiasi. Jumlah strategi pembelajaran yang ada sangat bervariasi, dalam hal ini guru memilih strategi pembelajaran berbasis masalah untuk meningkatkan keterampilan menulis teks negosiasi, dengan alasan pembelajaran berbasis masalah dapat mengembangkan kemampuan siswa berpikir kritis dan kreatif. Sesuai dengan hakikat dari pembelajaran berbasis masalah yaitu melatih dan mengembangkan kemampuan untuk menyelesaikan masalah yang berorientasi pada masalah otentik dari kehidupan aktual siswa demi merangsang kemampuan berpikir tingkat tinggi kondisi yang harus tetap dipelihara adalah suasana kondusif, terbuka, negosiasi, demokratis, serta suasana nyaman dan menyenangkan agar siswa dapat berpikir optimal. Indikator model pembelajaran ini adalah metakognitif, elaborasi (analisis), interpretasi, induksi, identifikasi, investigasi, eksplorasi, konjeksi, sintesis, generalisasi, dan inkuiri (Tampubolon, 2014).

Strategi pembelajaran berbasis masalah yang diterapkan nantinya akan meningkatkan keterampilan menulis teks negosiasi. Karena keterampilan menulis merupakan aktivitas mengemukakan gagasan melaui bahasa. Untuk menghasilkan tulisan yang baik, seorang penulis hendaknya memiliki tiga kemampuan dasar, meliputi: (1) keterampilan berbahasa, menggunakan ejaan, tanda baca, pembentukan kata, pemilihan kata, dan penggunaan kalimat efektif; (2) keterampilan penyajian, keterampilan pembentukan dan pengembangan paragraf, keterampilan merinci pokok bahasan menjadi sajian yang sistematis; (3) keterampilan perwajahan, keterampilan pengaturan tipografi dan pemanfaatan dan pemanfaatan sarana tulis secara efektif dan efisien, tipe huruf, penjilidan, penyusunan tabel, dan penyusunan lainnya.

Menulis teks negosiasi juga harus memerhatikan struktur dan ciri kebahasaan yang dimiliki teks negosiasi itu sendiri seperti: orientasi, pengajuan, penawaran, persetujuan, dan penutup. Kalimat penawaran harus persuasif yang bertujuan untuk 
meyakinkan atau membujuk lawan dan kesepakatan dalam dialog juga komponen yang harus ada dalam teks negosiasi.

Dalam buku siswa mata pelajaran bahasa Indonesia kurikulum 2013 (Kementerian Pendidikan dan Kebudayaan, 2016) dijelaskan bahwa teks negosiasi adalah bentuk interaksi sosial yang berfungsi untuk mencari penyelesaian bersama di antara pihak-pihak yang mempunyai perbedaan kepentingan. Pihak-pihak tersebut berusaha menyelesaikan perbedaan itu dengan cara-caranya.

Keterampilan menulis yaitu suatu proses perkembangan seseorang dalam melukiskan lambang-lambang grafik yang menggambarkan suatu bahasa yang dipahami oleh seseorang. Teks negosiasi adalah bentuk interaksi sosial yang bertujuan untuk mencari penyelesaian bersama diantara pihak-pihak yang mempunyai perbedaan kepentingan. Negosiasi juga dapat terjadi sebagai tanggapan terhadap usulan program dari pihak pertama kepada pihak kedua. Sebagai contoh, sebuah organisasi sosial sebagai pihak pertama mengajukan usulan program tentang pemberdayaan usaha rumah tangga di wilayah kecamatan tertentu kepada pemerintah kebupaten sebagai pihak kedua. Agar usulan itu menguntungkan kedua belah pihak, wakil dari setiap pihak perlu bertemu untuk melakukan negosiasi. Salah satu strategi yang cocok digunakan dalam pembelajaran materi teks negosiasi adalah strategi pembelajaran berbasis masalah yaitu rangkaian aktivitas pembelajaran yang menekankan pada proses penyelesaian masalah yang dihadapi secara ilmiah. Menurut Barron (Huda, 2014) pembelajaran berbasis masalah sebagai pembelajaran yang diperoleh melalui proses menuju pemahaman akan resolusi suatu masalah. Masalah tersebut dipertemukan pertama-tama dalam proses pembelajaran. Pembelajaran berbasis masalah berorientasi pada masalah, dengan masalah dalam pembelajaran diharapkan siswa menjadi berpikir kritis dan kreatif dalam menyelesaikan masalah. Adapun tujuan penelitian ini adalah untuk meningkatkan keterampilan menulis teks negosiasi melalui penerapan strategi pembelajaran berbasis masalah pada siswa kelas X MIPA 2 SMA Negeri 2 Labuapi.

\section{Metode Penelitian}

Penelitian ini merupakan penelitian tindakan kelas (PTK) yang dilakukan di SMA Negeri 2 Labuapi. Kelas yang digunakan untuk penelitian adalah kelas X MIPA 2 berjumlah 25 orang, dengan perincian 8 siswa laki-laki dan 17 siswa perempuan. Pemilihan subjek didasarkan atas keterampilan menulis teks negosiasi siswa yang dinilai masih rendah. Selain itu secara kebetulan peneliti bertugas mengajar pada kelas X MIPA 2 SMA Negeri 2 Labuapi. Dalam penelitian ini mencakup langkah-langkah: (1) persiapan, (2) studi/survei awal, (3) pelaksanaan siklus, dan (4) penyusunan laporan. Pelaksanaan siklus meliputi (a) perencanaan tindakan (planning), (b) pelaksanaan tindakan (acting), (c) pengamatan (observing), (d) refleksi (reflecting). Adapun instrumen penelitian ini menggunakan tes, observasi, analisis dokumen, wawancara, dan angket. Sedangkan teknik analisis data penelitian ini menggunakan analisis deskriptif kualitatif dan kuantitatif.

\section{Hasil Penelitian dan Pembahasan}

Kegiatan yang pertama dilakukan oleh peneliti ialah kegiatan pra siklus. Kegiatan pra siklus bertujuan untuk mengetahui kondisi awal subjek penelitian sebelum strategi atau tindakan dilakukan. Dalam kegiatan prasiklus, selain untuk mengetahui permasalahan pembelajaran yang dihadapi, peneliti juga mengamati proses pembelajaran dan melakukan wawancara dengan siswa. Hasil kegiatan pra siklus dalam penelitian ini dapat dilihat pada tabel di bawah ini. 
Tabel 1. Persentase Hasil Ketuntasan Pra Siklus

\begin{tabular}{|c|c|c|c|}
\hline \multirow{2}{*}{ No } & \multirow{2}{*}{ Ketuntasan } & \multicolumn{2}{|c|}{ Jumlah Siswa } \\
\cline { 3 - 4 } & & Jumlah & Persentase \\
\hline 1 & Tuntas & 9 & $36 \%$ \\
\hline 2 & Belum Tuntas & 16 & $64 \%$ \\
\hline & Jumlah & $\mathbf{2 5}$ & $\mathbf{1 0 0 \%}$ \\
\hline
\end{tabular}

Berdasarkan hasil tes pra siklus, menunjukkan bahwa dari 25 siswa, hanya 9 (36\%) orang siswa yang tuntas hasil belajarnya, sedangkan $16(64 \%)$ orang siswa belum dinyatakan tuntas. Setelah mengetahui kondisi awal subjek yang diteliti lalu peneliti mulai menerapkan strategi yang sudah dipersiapkan yaitu strategi pembelajaran berbasis masalah.

\section{Deskripsi Siklus I}

\section{Perencanaan}

Pada tahap perencanaan yang dilakukan oleh peneliti atau guru yaitu sebagai berikut.

a) Menyiapkan perangkat pembelajaran yang digunakan, seperti RPP, power point, dan video demo buruh yang diunduh dari internet. Materi pada pertemuan pertama siklus 1 adalah pengertian teks negosiasi, struktur teks negosiasi, dan mencari persamaan struktur isi dan ciri kebahasaan dari dua teks negosiasi yang berbeda. Materi pada pertemuan kedua siklus 1 adalah langkah-langkah menulis teks negosiasi dan memproduksi teks negosiasi.

b) Memilih strategi pembelajaran berbasis masalah dalam pembelajaran menulis teks negosiasi.

c) Menyiapkan materi teks negosiasi dari beberapa sumber buku dan dua teks negosiasi dari buku paket kelas $\mathrm{X}$.

d) Menyiapkan lembar observasi untuk pengamatan siswa dan guru pada saat proses pembelajaran.

e) Menyiapkan catatan lapangan dan kamera.

\section{Pelaksanaan Tindakan}

Pada pertemuan pertama siklus 1, guru membuka pelajaran dengan mengucapkan salam kemudian siswa menjawab salam dilanjutkan dengan guru melakukan presensi siswa. Sebelum memulai pelajaran, guru menjelaskan kepada kepada siswa bahwa akan diadakan penelitian di kelasnya, kemudian guru mempersilahkan peneliti duduk di belakang.

Guru memulai pelajaran dengan menjelaskan sedikit tentang teks negosiasi. Siswa mengamati penjelasan dari guru terkait teks negosiasi, kemudian siswa membaca informasi tentang teks negosiasi dari buku atau pun internet. Pada proses pembelajaran kali ini siswa diperbolehkan menggunakan telepon genggamnya untuk digunakan mencari informasi seputar materi yang sedang dipelajari. Setelah guru membagikan dua teks negosiasi yang berbeda, siswa berdiskusi dengan teman satu meja untuk mengamati kedua teks tersebut. Siswa mendapat tugas dari guru untuk mencari persamaan dan perbedaan struktur isi dan ciri kebahasaan dari dua teks negosiasi yang berbeda tersebut. Sekitar 35 menit siswa berdiskusi dengan teman satu mejanya, kemudian dilanjutkan dengan menyimpulkan hasil temuan mereka terkait perbedaan dan persamaan struktur isi dan ciri kebahasaan dua teks negosiasi. Proses terakhir dari pembelajaran yaitu guru menyimpulkan pembelajaran dan memberikan tugas kepada siswa untuk mencari contoh teks negosiasi dari sumber yang lain. 
Pertemuan 2; Guru membuka pelajaran dengan mengucap salam. Sebelum memulai pembelajaran guru mempresensi siswa, setelah itu guru menjelaskan tentang strategi pembelajaran berbasis masalah yang akan digunakan dalam menulis teks negosiasi. Guru juga menjelaskan tentang langkah-langkah menulis teks negosiasi dengan menggunakan strategi pembelajaran berbasis masalah dalam bentuk power point. Awal proses pembelajaran menulis teks negosiasi dengan menggunakan strategi pembelajaran berbasis masalah yaitu guru menampilkan video tentang berita demo buruh perempuan yang diunduh dari internet. Siswa terlihat antusias dalam menyimak video tersebut, sesekali terlihat siswa mencatat halhal yang penting dari video tersebut. Guru memutar video dua kali agar siswa lebih paham isi dari video.

Tahap selanjutnya siswa berdiskusi dengan teman sebelahnya tentang permasalahan yang ada di video. Siswa mendiskusikan penyelesaian dari masalah tersebut dan memberikan solusi dari masalah tersebut. Siswa terlihat antusias dalam berdiskusi dengan teman sebelahnya. Setelah mereka menemukan penyelesaian dan solusi, mereka menuliskannya ke dalam teks negosiasi. Sebelum mengakhiri pelajaran guru sempat menyakan kepada siswa "apakah pembelajaran menulis teks negosiasi dengan strategi pembelajaran berbasis masalah menyenangkan?" siswa serempak menjawab "iya bu, menulis teks negosiasi menjadi lebih mudah dengan strategi ini”.

\section{Pengamatan}

Pengamatan dilakukan peneliti pada dua aspek yaitu pengamatan proses dan pengamatan produk. Pengamatan proses dilakukan dengan menggunakan lembar observasi, sedangkan pengamatan produk yaitu mengamati nilai menulis teks negosiasi. Pengamatan proses dilakukan untuk mengetahui kekurangan dalam proses pembelajaran, sedangkan pengamatan produk dilakukan untuk mengetahui apakah ada peningkatan dalam pembelajaran menulis teks negosiasi dengan menggunakan strategi pembelajaran berbasis masalah atau tidak.

Keaktifan siswa pada pertemuan pertama termasuk cukup dan pada pertemuan kedua, ada beberapa peningkatan dari pertemuan pertama. Pada pertemuan kedua siswa sudah mulai berani mengajukan ide dan bertanya yang pada pertemuan pertama siswa masih bingung dan tidak tahu yang akan ditanyakan. Siswa juga mulai terlihat antusias dalam mengikuti pembelajaran, terbukti dengan mereka menyimak penjelasan tentang langkah-langkah menulis teks negosiasi yang disampaikan oleh guru dengan cermat. Pengamatan produk dilakukan untuk mengetahui apakah ada peningkatan nilai menulis teks negosiasi dengan menggunakan strategi pembelajaran berbasis masalah atau tidak. Dalam melakukan tahaptahap dalam siklus I, guru atau peneliti melakukan observasi, meneliti dan mengevaluasi hasil belajar siswa. Berdasarkan observasi yang dilakukan oleh peneliti terhadap pelaksanaan siklus I diperoleh keterangan sebagai berikut:

Tabel 2. Persentase Hasil Ketuntasan Siklus I

\begin{tabular}{|l|l|l|l|}
\hline \multirow{2}{*}{ No } & \multirow{2}{*}{ Ketuntasan } & Jumlah Siswa \\
\cline { 3 - 4 } & & Jumlah & Persentase \\
\hline 1 & Tuntas & 19 & $76 \%$ \\
\hline 2 & Belum Tuntas & 6 & $24 \%$ \\
\hline \multicolumn{2}{|l}{ Jumlah } & $\mathbf{2 5}$ & $\mathbf{1 0 0 \%}$ \\
\hline
\end{tabular}


Berdasarkan hasil penelitian Siklus I pada tabel 2 di atas, menunjukkan bahwa dari 25 siswa, $19(76 \%)$ orang siswa tuntas hasil belajarnya dan sedangkan 6 (24\%) orang siswa belum tuntas hasil belajarnya.

\section{Refleksi}

Setelah melakukan tindakan dan pengamatan, peneliti melakukan refleksi terhadap penelitian yang telah dilakukan. Hasil dari refleksi yang dilakukan oleh peneliti dan guru yaitu sebagai berikut.

a) Siswa masih banyak yang menggunakan penyingkatan kata, masih banyak kesalahan huruf kapital, dan tanda titik serta koma belum jelas.

b) Diskusi kelompok sudah berjalan dengan baik, tetapi masih ada siswa yang belum aktif dalam berdiskusi.

c) Siswa masih kurang memahami struktur teks negosiasi.

d) Siswa masih bingung menuliskan apa yang ada dipikiran mereka.

e) Tema perburuhan kurang diminati oleh siswa.

Berdasarkan pada hasil observasi dapat direfleksikan hasil antara pra siklus dengan siklus I terlihat adanya peningkatan jumlah siswa yang mencapai ketuntasan belajar. Namun belum mencapai target yang diaharapkan, maka perlu dilakukan perbaikan pada siklus II.

\section{Deskripsi Siklus II \\ Perencanaan}

Pada tahap perencanaan, yang dilakukan oleh peneliti dan guru adalah sebagai berikut.

a) Menyiapkan perangkat pembelajaran yang digunakan, seperti RPP, power point, dan gambar kegiatan di pasar dan toko usaha. Materipembelajaran pada pertemuan pertama siklus II adalah evaluasi menulis pada siklus I, kemudian membuat kerangka teks negosiasi dari gambar yang ditampilkan oleh guru, selanjutnya pada pertemuan kedua yaitu menulis teks negosiasi secara utuh.

b) Menyiapkan contoh teks negosiasi tentang perdagangan yang sudah divalidasi oleh guru.

c) Menyiapkan lembar observasi siswa dan guru.

d) Menyiapkan catatan lapangan dan kamera.

\section{Pelaksanaan}

Pelaksanaan Penelitian Tindakan Kelas (PTK) pada siklus II terlaksana dua kali pertemuan. Guru membuka pelajaran dengan mengucap salam, kemudian siswa menjawab salam dari guru. Proses pembelajaran pada pertemuan pertama dimulai dengan guru melakukan presensi pada siswa. Guru menjelaskan kepada siswa tentang strategi pembelajaran yang akan digunakan serta mengkomunikasikan tujuan pembelajaran yang diharapkan kepada seluruh siswa. Guru menyampaikan evaluasi menulis teks negosiasi pada siklus I dan mengulang sedikit tentang teks negosiasi. Guru menanyakan kepada siswa apakah tema perburuhan terlalu sulit, kemudian beberapa siswa menjawab iya. Pada siklus kedua ini guru dan peneliti sepakat untuk menggganti tema teks negosiasi dengan perdagangan dan kewirausahaan atau yang lainnya, dengan harapan siswa mudah dalam menulis masalah ke dalam bentuk teks negosiasi. Tahap selanjutnya guru meminta siswa menyebutkan permasalahan apa saja yang ada di pikiran mereka berkaitan dengan perdagangan dan kewirausahaan yang ada di lingkungan sekitar mereka, guru menggunakan bantuan gambar untuk mempermudah siswa dalam menentukan masalah. Siswa mulai menentukan masalah yang ada di pikiran mereka, siswa diperbolehkan mencari informasi tentang permasalahan yang mereka pilih dengan menggunakan telepon genggam. Tugas siswa pada pertemuan ini yaitu membuat kerangka 
teks negosiasi. Peran guru dalam pembelajaran ini sebagai fasilitator, dan pembimbingan dalam membantu siswa menentukan masalah, penyelesaian, dan solusi.

Akhir pembelajaran guru menyuruh siswa untuk mengumpulkan kertas yang digunakan siswa dalam menulis kerangka teks negosiasi. Guru memberitahu siswa bahwa pertemuan selanjutnya melanjutkan menulis teks negosiasi secara utuh. Guru menutup pelajaran dengan salam. Guru membuka pembelajaran dengan salam, siswa menjawab salam dari guru. Proses pembelajaran pertemuan kedua siklus II dimulai dengan guru melakukan presensi siswa. Guru membagikan kertas yang pada pertemuan pertama digunakan siswa untuk menulis kerangka teks negosiasi. Guru menampilkan contoh teks negosiasi. Setelah guru membagikan kertas yang dikumpulkan pada pertemuan 1, siswa mulai menulis teks negosiasi berdasarkan kerangka yang sudah mereka buat. Siswa terlihat serius dalam menulis. Guru berputar mengamati siswa, dan melakukan pembimbingan kepada siswa yang membutuhkan bimbingan. Tahap selanjutnya guru mempersilahkan peneliti untuk membagikan angket tanggapan siswa. Setelah itu peneliti mengucapkan terimakasih kepada siswa telah membantu dalam pengambilan data guna menyusun tugas akhir. Terakhir, guru dan peneliti mengucapkan salam dan meninggalkan kelas.

\section{Pengamatan}

Pengamatan dilakukan oleh guru dan peneliti menggunakan lembar observasi dan dokumentasi sebagai pengamatan proses, sedangkan nilai siswa sebagai pengamatan produk. Hasil pengamatan proses pembelajaran menulis teks negosiasi dengan menggunakan strategi pembelajaran berbasis masalah akan disajikan dalam bentuk tabel lembar observasi seperti berikut ini. Berdasarkan hasil lembar observasi siswa tersebut dapat disimpulkan ada beberapa peningkatan pada beberapa aspek. Peningkatan yang pertama yaitu pada aspek minat belajar siswa, antusias siswa dalam mengikuti pembelajaran, dan interaksi siswa dalam berkelompok. Peningkatan yang kedua yaitu pada aspek perhatian siswa, siswa mulai tenang dan fokus pada materi. Salah satunya yaitu minat belajar siswa dan perhatian siswa. Pengamatan Produk pada siklus II dilakukan dengan mengamati nilai hasil menulis teks negosiasi. Berikut ini tabel nilai siswa pada siklus II. Hasil tindakan pembelajaran pada siklus II berupa hasil tes dan non tes. Berdasarkan penelitian dan observasi yang dilakukan oleh guru sebagai peneliti terhadap pelaksanaan siklus II diperoleh keterangan sebagai berikut:

Tabel 3. Persentase Hasil Ketuntasan Siklus II

\begin{tabular}{|l|l|l|l|}
\hline \multirow{2}{*}{ No } & \multirow{2}{*}{ Ketuntasan } & \multicolumn{2}{|l|}{ Jumlah Siswa } \\
\cline { 3 - 4 } & & Jumlah & Persentase \\
\hline 1 & Tuntas & 25 & $100,00 \%$ \\
\hline 2 & Belum Tuntas & 0 & $0,00 \%$ \\
\hline Jumlah & $\mathbf{2 5}$ & $\mathbf{1 0 0 \%}$ \\
\hline
\end{tabular}

Berdasarkan hasil penelitian pada siklus II, menunjukkan bahwa dari 25 siswa, semua $(100 \%)$ orang siswa tuntas hasil belajarnya. Proses pembelajaran pada siklus II menunjukkan adanya perubahan, dibandingkan dengan proses pembelajaran pada siklus I.

\section{Refleksi}

Refleksi pada siklus II dilakukan oleh guru. Hasil dari refleksi pada siklus II yaitu sebagai berikut. 
a) Penggunaan strategi pembelajaran berbasis masalah yang digunakan berjalan dengan baik dan menghasilkan produk sesuai yang diharapkan.

b) Sebagian besar siswa aktif dalam mengikuti pembelajaran.

c) Hampir seluruh siswa mengikuti pembelajaran dengan senang dan tenang.

d) Ada peningkatan nilai dan sikap sesuai yang diharapkan oleh peneliti dan guru.

Berdasarkan pada hasil observasi dapat direfleksikan hasil antara siklus I dengan siklus II terlihat bahwa seluruh siswa (100\%) telah mencapai ketuntasan belajar dan sudah target yang diaharapkan, maka tidak perlu dilakukan perbaikan pada siklus berikutnya.

\section{Pembahasan}

Berdasarkan hasil observasi dan hasil tes dan non tes yang dilakukan pada pra siklus, siklus I dan siklus II, maka dapat diuraikan sebagai berikut:

Tabel 4. Perbandingan Hasil Evaluasi

\begin{tabular}{|l|l|l|l|l|l|}
\hline \multirow{2}{*}{ No } & \multirow{2}{*}{ Uraian } & \multicolumn{2}{|c|}{ Siswa Yang Tuntas } & \multicolumn{2}{l|}{ Siswa Belum Tuntas } \\
\cline { 3 - 6 } & & Jumlah & $\%$ & Jumlah & $\%$ \\
\hline 1 & Pra Siklus & 9 & $36 \%$ & 16 & $64 \%$ \\
\hline 2 & Siklus I & 19 & $76 \%$ & 6 & $24 \%$ \\
\hline 3 & Siklus II & 25 & $100,00 \%$ & 0 & $0,00 \%$ \\
\hline
\end{tabular}

Pada saat evaluasi dan observasi pada pra siklus terdapat 9 orang siswa (36\%) yang memiliki nilai tuntas. Setelah dilakukan tindakan hasil evaluasi menunjukkan terdapat kenaikan dalam hasil belajar siswa, yang tuntas belajar dari 19 siswa (76 \%) pada siklus I, dan menjadi 25 siswa $(100 \%)$ pada siklus II, sedangkan yang belum tuntas belajar mengalami penurunan dari 16 siswa (64\%) pada pra siklus menjadi 6 siswa (24\%) pada siklus I tidak ada siswa yang tidak tuntas $(100 \%)$ pada siklus II.

\section{Kesimpulan}

Berdasarkan hasil penelitian tindakan kelas ini, maka dapat diambil simpulan sebagai berikut: (1) Penerapan strategi pembelajaran berbasis masalah dapat meningkatkan keaktifan siswa dalam proses kegiatan belajar mengajarpembelajaran. (2) Penerapan strategi pembelajaran berbasis masalah dapat meningkatkan hasil belajar menulis teks negosiasi siswa kelas X MIPA 2 SMA Negeri 2 Labuapi tahun pelajaran 2019-2020. Peningkatan tersebut dapat dilihat dari peningkatan persentase ketuntasan belajar pada tiap siklusnya.

\section{Saran}

Berdasarkan hasil penelitian yang telah dilakukan teradapat beberapa saran yang disampaikan antara lain, yakni; Guru sebaiknya : (1) tidak segan untuk menyusun rencana pelaksanaan pembelajaran yang matang sebelum melaksanakan pembelajaran; (2) menyiapkan segala kebutuhan sesuai dengan rencana pelaksanaan pembelajaran yang sudah disusun; (3) menggunakan model pembelajaran yang inovatif sehingga siswa lebih antusias dalam kegiatan belajar mengajar sehingga tujuan pembelajaran dapat tercapai; Siswa harus (1) menyadari bahwa belajar teks negosiasi menyenangkan dan memberikan manfaat bagi kehidupan bersosial; (2) lebih aktif dan tidak mudah putus asa bila mengalami kesulitan dalam memahami materi pelajaran yang disampaikan oleh guru. 


\section{Daftar Pustaka}

Huda, Miftahul. (2014). Model-Model Pengajaran dan Pembelajaran. Yogyakarta:Pustaka Pelajar.

Fitriani, F., \& Kurniawati, W. (2017). MENINGKATKAN KEMAMPUAN MENULIS CERPEN SISWA MELALUI PENGGUNAAN MEDIA LAGU DAERAH SUMBAWA PADA MATA PELAJARAN BAHASA INDONESIA DI SMAN 1 SEKONGKANG. Jurnal Teknologi Pendidikan, 2(1), 24-29. Retrieved from http://ojs.ikipmataram.ac.id/index.php/jtp/article/view/617

Jayanti, F., \& Fachrurazi, F. (2020). Peningkatan Keterampilan Menulis Karangan Deskripsi Melalui Metode Discovery dengan Menggunakan Media Gambar pada Mahasiswa Program Studi Pendidikan Bahasa dan Sastra Indonesia STKIP Pontianak. Jurnal Kependidikan: Jurnal Hasil Penelitian dan Kajian Kepustakaan di Bidang Pendidikan, Pengajaran dan Pembelajaran, 6(2), 329-339. doi:https://doi.org/10.33394/jk.v6i2.2491

Jihad, Asep dan Abdul Haris. (2008). Evaluasi Pembelajaran. Yogyakarta: Multi Pressindo.

Kementrian Pendidikan dan Kebudayaan. (2016). Bahasa Indonesia. Jakarta: Pusat Kurikulum dan Perbukuan, Balitbang Kemdikbud.

Kunandar. (2008). Langkah Mudah Penelitian Tindakan Kelas Sebagai Pengembangan Profesi Guru. Jakarta: Rajawali Pers.

Kusumah, Wijaya., dan Dedi Dwitagama. (2009). Mengenal Penelitian TindakanKelas. Jakarta: PT Malta Printindo.

Lewicki, Roy J., Bruce Barry, dan David M. Saunders. (2012). Negosiasi. Jakarta: Salemba Humanika.

Purwanto, Ngalim. (2010). Prinsip-Prinsip dan Teknik Evaluasi Pengajaran. Bandung: PT Remaja Rosdakarya.

Rusmono. (2014). Strategi Pembelajaran dengan Problem Based Learning Itu Perlu. Bogor: Ghalia Indonesia.

Sahra, S. (2020). Peningkatan Keterampilan Menulis Kreatif Puisi Bebas Melalui Media Batu bagi Siswa SMPN 15 Mataram. Jurnal Paedagogy, 7(4), 330-338. doi:https://doi.org/10.33394/jp.v7i4.2892

Sanjaya, W. (2006). Strategi Pembelajaran. Jakarta: Kencana Prenada Media Group.

Sanjaya, Wina. (2007). Strategi Pembelajaran Berorientasi Standar Proses Pendidikan. Jakarta: Kencana.

Sukmadinata, Nana Syaodih. (2016). Metode Penelitian Pendidikan. Bandung:Remaja Rosdakarya.

Tampubolon, Saur. (2014). Penelitian Tindakan Kelas Sebagai Pengembangan Profesi Pendidik dan Keilmuan. Jakarta: Erlangga.

Tarigan, Henry Guntur. (2008). Menulis Sebagai Salah Satu Keterampilan Berbahasa. Bandung: Angkasa. 